Original Full Paper

\title{
In vitro and in vivo antiparasitic action of essential oils of Lippia spp. in Koi Carp (Cyprinus carpio) fed supplemented diets
}

\author{
Elenice M. Brasil ${ }^{1 *}$, Aline B. Figueredo ${ }^{1,2}$, Lucas Cardoso ${ }^{1}$, Marcio Q. de C. Santos ${ }^{3}$, Elisabeth de A. \\ Bertaglia $^{1}$, William E. Furtado ${ }^{1}$, Jeanderson da S. Viana ${ }^{5}$, Iracimar B. do Carmo ${ }^{6}$, Francisco C. M. \\ Chaves $^{4}$, José L. P. Mouriño ${ }^{1}$, Maurício L. Martins ${ }^{1}$ \\ ${ }^{1}$ AQUOS - Aquatic Organisms Health Laboratory, Department of Aquaculture, School of Agricultural Sciences (CCA), Federal University of Santa \\ Catarina (UFSC), Rod. Admar Gonzaga 1346, 88040-900, Florianópolis, SC, Brazil. \\ ${ }^{2}$ Department of Fisheries Engineering and Biological Sciences, Santa Catarina State University (UDESC), R. Cel. Fernandes Martins, 270, 88790-000, \\ Laguna, Santa Catarina, Brazil. \\ ${ }^{3}$ Federal Institute of Education, Science and Technology of Amazonas (IFAM), Campus Coari, Estrada Coari Itapéua, Km 2 s/n, Itamaraty, 69460-000, \\ Coari, Amazonas, Brazil. \\ ${ }^{4}$ Embrapa Western Amazonia, Rod. AM 10, km 29 s/n, 69010-970, Manaus, Amazonas, Brazil. \\ ${ }^{5}$ Laboratory of Biology and Cultivation of Freshwater Fish, Federal University of Santa Catarina, Aquaculture Department, Rod. Francisco Thomaz dos \\ Santos 3532, Florianópolis, Santa Catarina, 88066-260, Brazil. \\ ${ }^{6}$ State Department of Education and Quality of Education of Amazonas (SEDUC). Rua Waldomiro Lustoza, 250, Japiim II, 69076-830, Manaus, \\ Amazonas, Brazil. \\ *Corresponding author: Elenice Martins Brasil. AQUOS - Aquatic Organisms Health Laboratory, Department of Aquaculture, School of Agricultural \\ Sciences (CCA), Federal University of Santa Catarina (UFSC), Rod. Admar Gonzaga 1346, 88040-900, Florianópolis, SC, Brazil.
}

Submitted March, $8^{\text {th }} 2019$, Accepted July, $7^{\text {th }} 2019$

\begin{abstract}
This study evaluated the in vitro antiparasitic activity of the essential oils of Lippia alba, $L$. origanoides and $L$. sidoides against monogenean parasites of koi carp Cyprinus carpio and its zootechnical performance in net cages. The oils were obtained from the leaves by hydro distillation, and the chemical composition was evaluated via gas chromatography. In vitro assays were performed with each essential oil separately and combined in binary (1:1) and tertiary (1:1:1) mixtures with the Lippia species at 10,20, 40,60, 80 and $100 \mathrm{mg} \mathrm{L}^{-1}$ and two control groups (grain alcohol and tank water). To determine zootechnical performance, $L$. sidoides oil was added to the feed at 0.00 (control), 0.25, 0.50, 0.75 and $1 \%$, in triplicate and with 20 fish per net cage fed for 60 days. The best results in vitro against monogeneans were observed for $L$. sidoides ( $40 \mathrm{mg} \mathrm{L}^{-1}$ in $8 \mathrm{~min}$ ), followed by L. origanoides ( $40 \mathrm{mg} \mathrm{L}^{-1}$ in $25 \mathrm{~min}$ ) and L. alba (40 $\mathrm{mg} \mathrm{L}^{-1}$ in $4 \mathrm{~h}$ ). Reductions in weight gain, protein efficiency rate and specific growth rate were observed in diets containing $0.75 \%$ of $L$. sidoides oil in comparison to the control and the $0.25 \%$ diet. There were no significant differences in growth, individual mean feed intake, apparent feed conversion and parasitological indices. Based on our results, $0.25 \%$ L. sidoides oil showed the best zootechnical performance, but was not effective against koi carp parasites in vivo.
\end{abstract}

Key words: fish farming, phytotherapics, efficacy, ectoparasites.

\section{Introduction}

Koi carp (Cyprinus carpio) is the most widely cultured ornamental fish species in the world and the second best-selling exotic species in Brazil after the goldfish (Carassius auratus). The southeastern and eastern regions have the highest farming volumes of koi carp, and along with the marketing of other ornamental fish species, they move more than $\mathrm{R} \$ 700$ million per year $(50,74)$. Despite the economic importance of koi carp, studies on the parasitic issues and the use of essential oils in the diet as antiparasitic treatment are still scarce. Fish health is a 
constant concern of ornamental fish farmers, and the Ministry of Fisheries has launched manuals of good management practices, as chronic stress and fish losses in the farms occur mainly in intensive systems with high stocking densities $(88,13)$. Among intensive culture systems in net tanks, floating structures have an advantage regarding the easy catching of the fish and the possibility of growing several species at different stocking densities. However, intensive systems with high stocking densities can cause stress to animals, because the closer physical contact among fish can facilitate the proliferation of diseases caused by parasites such as monogeneans, cestodes and trichodinids $(68,56)$. The most common monogeneans found in the gills and skin of koi carp is Dactylogyrids (12). In the state of Santa Catarina, Brazil, two species have been identified, Dactylogyrus extensus Mueller et Van Cleave, 1932 and Dactylogyrus minutus Kulwiec, 1927 (71). Trichodinids are globally distributed and mainly parasitize the body surface and gills of fish. Some species can be endoparasites and cause serious lesions that can serve as a gateway for other pathogenic agents such as bacteria $(42,84)$. Regarding the trichodinid species reported in koi carp, Trichodina mutabilis Kazubski and Migala, 1968 (46) and Trichodina sp. (71) have already been identified in the state of Santa Catarina. These parasites reproduce rapidly under conditions such as poor water quality, high stocking density and immunosuppressed hosts, which are most susceptible to severe infestations, and can cause mortality in all fish life stages (27), necessitating strict control in farming systems.

Fish farmers control parasites by using chemicals such as praziquantel, mebendazole and levamisole (55), but the continuous and inadequate use of these products can result in serious environmental contamination, pathological changes in fish, risks to human health and resistance of the pathogens to the active principles of chemotherapeutic agents (64). These factors have stimulated the search for alternatives to minimise these negative effects. Within this context, certain plant-based products are effective in the prevention, control and treatment of bacterial and parasitic diseases in fish (44, 38). Studies have shown that some plants have antiparasitic properties for fish and other animals $(87,82)$.

Among the plant species studied for therapeutics are those from the family Verbenaceae, with emphasis on the genus Lippia, which presents diverse biological activities and is used for the treatment of respiratory diseases, menstrual disorders and as analgesics and sedative in humans $(40,39,18)$. This genus is native to Brazil and can tolerate various types of environments, grows rapidly and is rich in essential oils, with yields varying from 2.44 to $4.4 \%(92,89)$. Among the species with therapeutic importance are bushy matgrass (Lippia alba), oregano (Lippia origanoides) and pepper rosemary (Lippia sidoides), whose essential oils have antimicrobial, antitumor, antifungal, antiparasitic and anaesthetic activities $(57,7,53,38)$.
Lippia alba has antimicrobial activity against Aeromonas hydrophila (79), fungicidal action against Trichophyton rubrum, Epidermophyton floccosum and Microsporum gypseum (19), besides acting as stress reducer in the transport of silver catfish Rhamdia quelen juveniles (7) and as an anaesthetic for $R$. quelen (33, 80, 78). Lippia origanoides has antimicrobial activity against Staphylococcus aureus, Escherichia coli, Salmonella choleraesuis (5) and Aeromonas hydrophila (51), fungicidal action against Aspergillus fumigatus (10) and antiparasitic effect against monogeneans from tambaqui Colossoma macropomum (77).

Lippia sidoides presents fungicidal action against Candida spp. (30), antimicrobial activity against Staphylococcus aureus, Escherichia coli (17) and Aeromonas hydrophila (51) and antiparasitic activity against monogeneans from tambaqui $C$. macropomum and tilapia Oreochromis niloticus $(38,77)$. In view of the positive results regarding the use of these essential oils, this study aimed to evaluate the efficacy of the essential oils from L. alba, L. origanoides and L. sidoides against monogenean and trichodinid parasites in koi carp. We evaluated both in vitro and in vivo effects after dietary supplementation, verifying their impacts on zootechnical performance.

\section{Materials and methods}

\section{Biological material}

Koi carp (Cyprinus carpio) used for in vitro and in vivo assays were obtained from "Vale dos Bettas" fish farm located in the municipality of Biguaçu, Santa Catarina State, Southern Brazil. In vitro and in vivo assays were performed in this farm. For in vitro assays, parasites were collected from carps with mean weight of $3.61 \pm 0.56$ $\mathrm{g}$ and standard length $4.71 \pm 0.54 \mathrm{~cm}$. The in vivo assay was performed in $1.0 \times 1.0 \times 1.30 \mathrm{~m}$ net tanks with $0.5 \mathrm{~cm}$ mesh opening, installed in a pond with approximately 1 hectare of total area. All animal procedures were approved by the Ethic Committee on Animal Use of Federal University of Santa Catarina (CEUA/UFSC 1440100217).

\section{Chemical composition of the essential oils}

The essential oils were obtained from the leaves of plants cultivated and processed in the Medicinal Plants and Phytochemistry Laboratory of EMBRAPA Western Amazon, Manaus- AM, Brazil. After the leaves were collected in the morning, they were dried in a continuous circulation oven at $45^{\circ} \mathrm{C}$ for $48 \mathrm{~h}$ and then the extraction of the essential oils was performed by hydro distillation process in a Clevenger type apparatus $(56,70)$.

The chemical composition of the oils from $L$. alba, L. origanoides and $L$. sidoides was determined by gas chromatographic method with Agilent 6890 equipment and selective mass detector Agilent 5973N. The separation of 
the components was performed on a capillary column HP5-MS (30 m x $0.25 \mathrm{~mm} \times 0.25 \mu \mathrm{m}$ ) with temperature of $60^{\circ} \mathrm{C}$ to $240^{\circ} \mathrm{C}$ and variation of $3^{\circ} \mathrm{C} \mathrm{m} \mathrm{m}^{-1} .1 .0$ microliter of a solution containing $1 \%$ of each oil was injected into the flux splitter in the ratio of 1: 100 and maintained at $250^{\circ} \mathrm{C}$. The relative quantification $(\%)$ of the components of the oils was carried out in gas chromatograph Agilent 6890N, which was equipped with a flame ionization detector, maintained at $280^{\circ} \mathrm{C}$, and by an HP5 capillary column (30 $\mathrm{m} \times 0.32 \mathrm{~mm} \times 0.25 \mu \mathrm{m})$ with the use of hydrogen $(1.5 \mathrm{~mL}$ min-1) as carrier gas. The identification of the constituents of each oil was performed by comparing the mass spectra obtained by Wiley 6th edition spectra library and by comparing the calculated retention index of each component with literature data. The calculation of the index was performed by injecting a series of $n$-alkanes in the same analytical conditions used for the other oils (3).

In vitro test of the essential oils of Lippia alba, Lippia origanoides and Lippia sidoides separately and in combination

Initially, the three oils were tested in vitro at concentrations of $0.25 ; 0.5 ; 0.75$ and $1.0 \%$ to determine its effectiveness against monogenean parasites, for later testing in vivo. In these concentrations it was not possible to determine the oils efficacy, since the parasites died instantly. Thus, the experimental concentrations were changed for $10,20,40,60,80$ and $100 \mathrm{mg} \mathrm{L}^{-1}$ based on similar studies in the literature $(72,50)$.

For in vitro tests, koi carps were randomly captured, anesthetized with clove oil $\left(75 \mathrm{mg} \mathrm{L}^{-1}\right)$ and euthanized by medullar section for gill arches collection and confirmation of the presence of monogenean parasites with a dissecting microscope (Carl Zeiss Suzhou Co., model Square 3-B). After confirming the presence of parasites, solutions from the oils of the three species of Lippia were prepared. The essential oils were diluted in grain alcohol to a stock solution of $10 \%$ and soon thereafter the concentrations in the following proportions and treatments were prepared: control with water from fish tank, control with cereal alcohol, L. alba (10, 20, 40, 60, 80 and $\left.100 \mathrm{mg} \mathrm{L}^{-1}\right)$, L. origanoides $(10,20,40,60,80$ and $\left.100 \mathrm{mg} \mathrm{L}^{-1}\right)$, L. sidoides (10, 20, 40, 60, 80 and100 $\mathrm{mg} \mathrm{L}^{-}$ $\left.{ }^{1}\right)$, L. alba + L. origanoides (1:1 to $10,20,40,60,80$ and $\left.100 \mathrm{mg} \mathrm{L}^{-1}\right)$, L. alba + L. sidoides $(1: 1$ to $10,20,40,60,80$ and $\left.100 \mathrm{mg} \mathrm{L}^{-1}\right)$, L. origanoides + L. sidoides (1:1 to 10 , 20, 40, 60, 80 and $\left.100 \mathrm{mg} \mathrm{L}^{-1}\right)$, L. alba + L. origanoides + L. sidoides (1:1:1 to $10,20,40,60,80$ and $\left.100 \mathrm{mg} \mathrm{L}^{-1}\right)$.

The treatments were performed in triplicate in a six well microplate containing a parasitized gill filament per well. The plates were observed every $15 \mathrm{~min}$ for quantification of dead parasites and behavioral observations, with parasite death confirmed by absence of movement when stimulated with a needle. At concentrations of 10 and $20 \mathrm{mg} \mathrm{L}^{-1}$ of Lippia oils, parasite immobilization was observed in the first $20 \mathrm{~min}$ of exposure, followed by a recovery of the movements after $50 \mathrm{~min}$, therefore, for effective confirmation of mortality, the parasites were stimulated with a needle for up to $5 \mathrm{~h}$ after the start of the experiment.

In vivo test with Lippia sidoides essential oil supplemented in the diet

The essential oil of Lippia sidoides was selected for the in vivo assay since it presented higher efficacy against parasites in vitro. The essential oil was added to a commercial diet already used in the farm, containing $50 \%$ crude protein. The essential oil at concentrations $0.25 ; 0.5$; 0.75 and $1.0 \%$ was diluted in grain alcohol and added to the feed at the proportion $100 \mathrm{~g}$ of alcohol per $\mathrm{kg}$. The oil was weighed with the aid of a digital scale. The essential oil with its respective concentrations was placed in a hand sprayer and sprinkled on the feed, which was left to dry for 24 hours at room temperature and then stored in a freezer until the day of its use (21).

\section{In vivo assay in net cages}

Three hundred carps from the same pond with mean weight of $3.56 \pm 0.68 \mathrm{~g}$ were distributed in $1 \mathrm{x} 1 \mathrm{x}$ $1.30 \mathrm{~m}$ net tanks with $0.5 \mathrm{~cm}$ mesh opening. The experimental design consisted of five treatments, in triplicate: control (commercial feed without addition of essential oil), $0.25,0.50,0.75$ and $1.0 \%$ of Lippia sidoides essential oil. The fishes were fed twice a day (9 a.m. and 4 p.m.) for 60 days. During this period, water quality parameters remained at the following values: dissolved oxygen $6.08 \pm 1.55 \mathrm{mg} \mathrm{L}^{-1}$, temperature $20.50 \pm 0.88^{\circ} \mathrm{C}, \mathrm{pH}$ $5.40 \pm 0.82$, electrical conductivity $40.73 \pm 6.52 \mu \mathrm{S} \mathrm{cm}^{-3}$ and total suspended solids $19.25 \pm 4.20 \mathrm{mg} \mathrm{L}^{-1}$ measured with multiparameter instrument (Hanna HI 9828), total ammonia $0.58 \pm 0.27 \mathrm{mg} \mathrm{L}-1$ and nitrite $0 \mathrm{mg} \mathrm{L}-1$ measured with commercial colorimetric kit (Alcon pet ${ }^{\circledR}$ ) and transparency $24.17 \pm 1.83 \mathrm{~cm}$ measured with Secchi disk. At the beginning of the experiment and at the times of 30 and 60 days, biometrics of all the fish were performed for the calculation of zootechnical indexes and samples of six fish per experimental unit were collected for parasitological analysis.

\section{Growth performance parameters}

The calculations of daily weight gain, protein efficiency rate, mean individual feed intake, apparent feed conversion, specific growth rate and survival rate were performed using the formulas (30):

Weight gain $(\mathrm{g})=$ mean final weight $(\mathrm{g})-$ mean initial weight (g).

Protein efficiency rate $(\mathrm{PER})=$ weight gain $(\mathrm{g}) /$ ingested crude protein $(\mathrm{g})$.

Mean Individual Feed Intake $(\mathrm{MIFI})=$ provided feed $(\mathrm{kg}) /$ number of fish. 
Apparent feed conversion $(\mathrm{AFC})=\mathrm{MIFI} /[$ (mean final weight $(\mathrm{g})$ - mean initial weight $(\mathrm{g})$ ] .

Specific Growth Rate $(\mathrm{SGR})=100 \times$ (ln mean final weight - ln mean initial weight) / time.

Survival Rate $(\mathrm{SR})=100 \% \times$ (final number of fish/initial number of fish).

\section{Parasitological analysis}

Six fish per experimental unit were anesthetized in clove oil solution $\left(75 \mathrm{mg} \mathrm{L}^{-1}\right)$ and euthanized by brain section for collection of the branchial arches and mucus scraping. Gill arches were initially bathed in water at $55^{\circ} \mathrm{C}$ and then fixed in $70 \%$ ethanol. Mucus scraping was fixed in $70 \%$ ethanol and analyzed under microscope.

The quantification of parasites was calculated using the prevalence rate, mean intensity (41) and average parasite abundance (14). The monogeneans found in the experiment were mounted in Hoyer's medium between glass slide and cover slip for observation of sclerotized structures such as copulatory complex, horseradish bar, hooks and anchors (26), and identified according to (58) and (45). For trichodinids, the Klein method of silver impregnation (43) was applied for parasite identification $(60,77,24)$.

\section{Statistical analysis}

To evaluate the differences among the means, ANOVA was applied with significance level of 0.05 . Before the analysis, the data were tested for normality and homoscedasticity, and the data expressed as percentage were normalized by applying angular transformation. When necessary, Tukey test applied to confirm differences among means. Statistical analyzes were performed on GraphPad 4.03 software (La Jolla, CA, USA).

\section{Results}

\section{Chemical composition of the essential oils}

The analysis results of the chemical composition of $L$. sidoides, L. origanoides and $L$. alba are shown in Fig. 1. For $L$. sidoides, $100 \%$ of the chemical components were quantified and $99.4 \%$ identified. The compounds with the highest percentages were thymol $(72.2 \%)$, p-cymene $(8.15 \%)$ and (E)-caryophyllene $(4.9 \%)$. In L. origanoides, $100 \%$ of the compounds were quantified, and the most abundant ones were identified as p-cymene (37\%), carvacrol (14\%), y-terpinene (11.6\%) and linalool (6\%). In L. alba, $100 \%$ of the compounds were quantified, and $97.9 \%$ of the compounds were identified. The major constituents were carvone (58.2\%), limonene (19.2\%) and D-germacrene (3.8\%).
In vitro test of the essential oils of Lippia alba, Lippia origanoides and Lippia sidoides separately and in combination

The best result was assumed as the lowest concentration that killed monogenean Dactylogyrus minutus and Dactylogyrus extensus within the shortest time. Best results were obtained with $L$. sidoides and $L$. origanoides assessed separately, while the worst results were observed in the treatments containing only $L$. alba essential oil (Table 1). The treatments that presented $100 \%$ mortality with the lowest essential oil concentration within the shorted time were as follows: L. sidoides $\left(\geq 40 \mathrm{mg} \mathrm{L}^{-1}\right.$ in $8 \mathrm{~min}$ ), L. origanoides ( $\geq 60 \mathrm{mg} \mathrm{L}^{-1}$ in $9 \mathrm{~min}$ ) and $L$. alba $+L$. origanoides $\left(\geq 60 \mathrm{mg} \mathrm{L}^{-1}\right.$ in $\left.12 \mathrm{~min}\right)$.

In addition, in solutions containing concentrations of essential oils above $20 \mathrm{mg} \mathrm{L}^{-1}$, the monogenean parasites presented continuous contortions, followed by alterations in the body shape and the appearance of oedema, vacuolisation of internal structures and rupture of the internal membrane. There was a temporary neutralisation of parasite movements, even with needle stimulation, after the first $20 \mathrm{~min}$ of exposure to essential oils at concentrations of 10 and $20 \mathrm{mg} \mathrm{L}^{-1}$ and recovery of the movements after $50 \mathrm{~min}$ of the experiment in all treatments, with subsequent parasite mortality.

In vivo test with essential oil of Lippia sidoides

In the present study, the monogeneans Dactylogyrus minutus and Dactylogyrus extensus and the trichodinids Trichodina reticulata Hirschmann et Partsch, 1955, Trichodina heterodentata Duncan, 1977 and Trichodina sp. were identified. There was no fish mortality in any of the treatments; however, reductions in weight gain, protein efficiency rate and specific growth rate were observed in fish fed diets containing $0.75 \%$ of essential oil from $L$. sidoides in comparison to the control group and the animals fed a diet containing $0.25 \%$ of essential oil. The other parameters did not present significant differences $(p>0.05)$ among treatments (Table 2).

In the present study, the parasitological indices of koi carp fed $0.25 ; 0.5 ; 0.75$ and $1 \%$ L. sidoides essential oil were similar to those of the control at 30 days of feeding. There was no reduction in the parasitic load of the fish in the experimental period, with a prevalence of $72.22 \%$ and a mean intensity of 1.91 at the concentration of $1 \%$, while the control had a prevalence of $66.67 \%$ and a mean intensity of 2.06 .

Throughout the experimental period, the highest and lowest parasite prevalence values were 83.33 to $55.56 \%$, with mean intensities of 8.27 to 4.72 at concentrations of 0.25 and $0.50 \%$ of the oil, evidencing that $L$. sidoides essential oil was not effective at the concentrations tested for monogeneans (Table 3 ). 

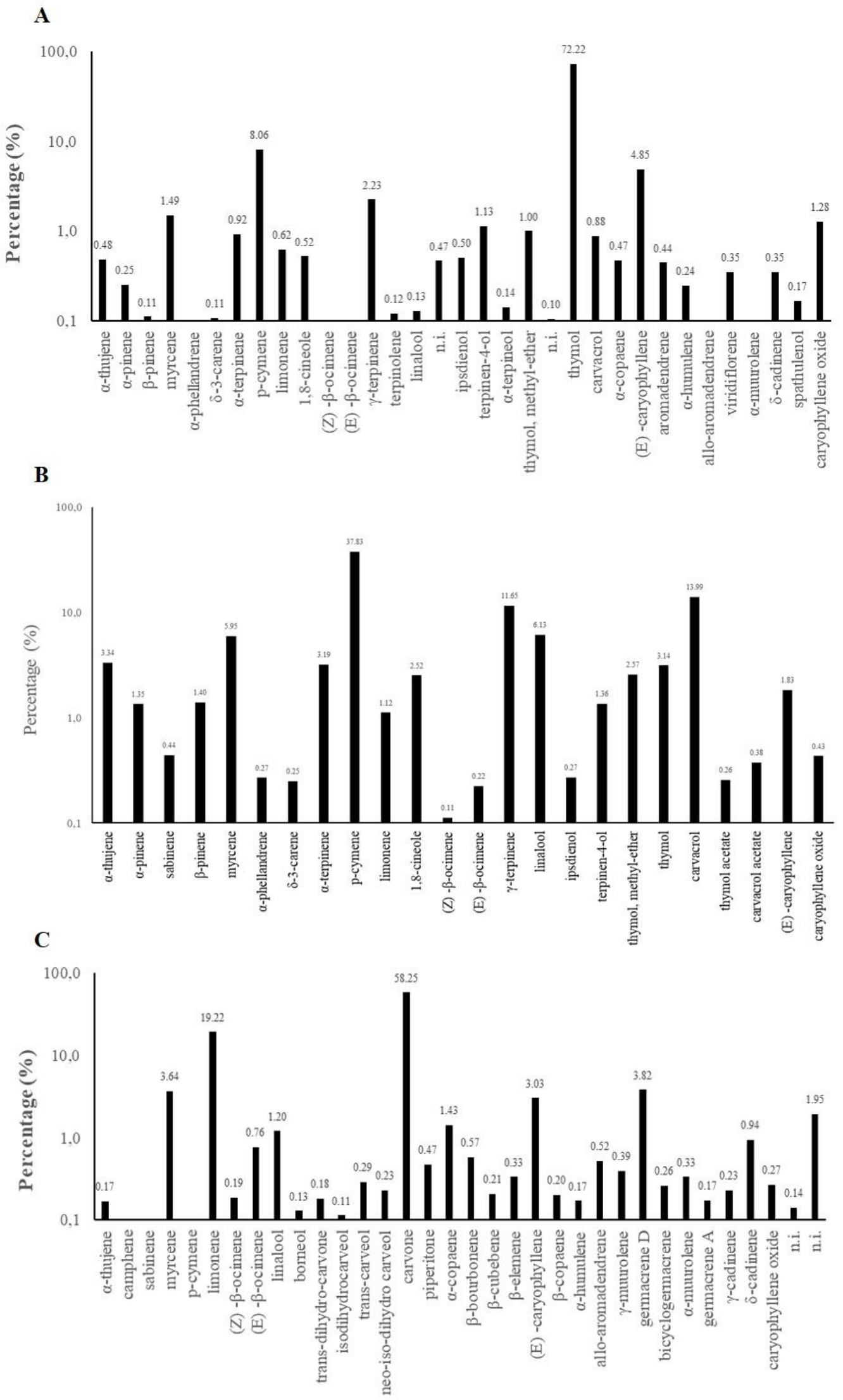

Figure 1. Chemical composition of the essential oils from A. Lippia sidoides B. Lippia origanoides and C. Lippia alba. 
Table 1. In vitro test with crescent levels of essential oils from Lippia alba, Lippia origanoides and Lippia sidoides, separately and in combination, at 10,20,40,60,80,100 $\mathrm{mg} \mathrm{L}^{-1}$, with water control and grain alcohol control.

\begin{tabular}{|c|c|c|c|c|}
\hline $\begin{array}{l}\text { Concentration of essential } \\
\text { oils }\left(\mathrm{mg} \mathrm{L}^{-1}\right)\end{array}$ & Mortality time & $\begin{array}{c}\text { Initial number of } \\
\text { parasites }\end{array}$ & $\begin{array}{c}\text { Final number of } \\
\text { dead parasites }\end{array}$ & Mortality rate (\%) \\
\hline Water control & $3 \mathrm{~h} 57 \mathrm{~min}$ & 23 & 23 & 100.00 \\
\hline Alcohol control & $5 \mathrm{~h} 29 \mathrm{~min}$ & 19 & 15 & 78.95 \\
\hline \multicolumn{5}{|l|}{ L. alba } \\
\hline 10 & $4 \mathrm{~h} 47 \min ^{\mathrm{a}^{* \#}}$ & 19 & 16 & 84.21 \\
\hline 20 & $4 \mathrm{~h} 48 \min ^{\mathrm{a}^{*}}$ & 29 & 27 & 93.10 \\
\hline 40 & $4 \mathrm{~h} 24 \min ^{\mathrm{a}^{*}}$ & 38 & 29 & 76.32 \\
\hline 60 & $4 \mathrm{~h} 12 \min ^{\mathrm{a}^{*}}$ & 32 & 25 & 78.13 \\
\hline 80 & $3 \mathrm{~h} 17 \min ^{\mathrm{b}^{*}}$ & 25 & 23 & 92.00 \\
\hline 100 & $3 \mathrm{~h} 12 \min ^{\mathrm{b} *}$ & 30 & 30 & 100.00 \\
\hline \multicolumn{5}{|l|}{ L. origanoides } \\
\hline 10 & $2 \mathrm{~h} 24 \min ^{\mathrm{a}}$ & 19 & 19 & 100.00 \\
\hline 20 & $1 \mathrm{~h} 45 \min ^{\mathrm{a}}$ & 16 & 16 & 100.00 \\
\hline 40 & $25 \min ^{\mathrm{b}}$ & 18 & 18 & 100.00 \\
\hline 60 & $9 \min ^{c}$ & 18 & 18 & 100.00 \\
\hline 80 & $7 \min ^{c}$ & 20 & 20 & 100.00 \\
\hline 100 & $5 \min ^{\mathrm{c}}$ & 18 & 18 & 100.00 \\
\hline \multicolumn{5}{|l|}{ L. sidoides } \\
\hline 10 & $2 \mathrm{~h} 58 \min ^{\mathrm{a}}$ & 20 & 20 & 100.00 \\
\hline 20 & $1 \mathrm{~h} 26 \min ^{\mathrm{b}}$ & 17 & 17 & 100.00 \\
\hline 40 & $8 \min ^{c}$ & 25 & 25 & 100.00 \\
\hline 60 & $6 \min ^{c}$ & 19 & 19 & 100.00 \\
\hline 80 & $7 \min ^{c}$ & 24 & 24 & 100.00 \\
\hline 100 & $5 \min ^{\mathrm{c}}$ & 17 & 17 & 100.00 \\
\hline \multicolumn{5}{|l|}{ L. alba + L. origanoides } \\
\hline 10 & $4 \mathrm{~h} 27 \min ^{\mathrm{a}^{*}}$ & 28 & 21 & 75.00 \\
\hline 20 & $4 \mathrm{~h} 53 \min ^{\mathrm{a}^{*}}$ & 25 & 16 & 64.00 \\
\hline 40 & $4 \mathrm{~h} 5 \min ^{\mathrm{a}^{*}}$ & 21 & 12 & 57.14 \\
\hline 60 & $12 \min ^{\mathrm{b}}$ & 23 & 23 & 100.00 \\
\hline 80 & $11 \min ^{\mathrm{b}}$ & 20 & 20 & 100.00 \\
\hline 100 & $8 \min ^{\mathrm{b}}$ & 22 & 22 & 100.00 \\
\hline \multicolumn{5}{|l|}{ L. alba + L. sidoides } \\
\hline 10 & $4 \mathrm{~h} 6 \min ^{\mathrm{a}^{*}}$ & 16 & 4 & 25.00 \\
\hline 20 & $4 \mathrm{~h} 6 \min ^{\mathrm{a}^{*}}$ & 24 & 14 & 58.33 \\
\hline 40 & $2 \mathrm{~h} 23 \min ^{\mathrm{b}}$ & 17 & 17 & 100.00 \\
\hline 60 & $20 \min ^{\mathrm{c}}$ & 21 & 21 & 100.00 \\
\hline 80 & $19 \min ^{\mathrm{c}}$ & 30 & 30 & 100.00 \\
\hline 100 & $6 \min ^{\mathrm{d}}$ & 16 & 16 & 100.00 \\
\hline \multicolumn{5}{|l|}{ L. origanoides + L. sidoides } \\
\hline 10 & $4 \mathrm{~h} 38 \min ^{\mathrm{a}^{*}}$ & 18 & 12 & 66.67 \\
\hline 20 & $4 \mathrm{~h} 37 \min ^{\mathrm{a}^{*}}$ & 18 & 9 & 50.00 \\
\hline 40 & $4 \mathrm{~h} 26 \min ^{\mathrm{a}^{*}}$ & 47 & 22 & 46.61 \\
\hline 60 & 1h $3 \min ^{\mathrm{b}}$ & 26 & 26 & 100.00 \\
\hline 80 & $8 \min ^{c}$ & 31 & 31 & 100.00 \\
\hline 100 & $6 \min ^{\mathrm{c}}$ & 22 & 22 & 100.00 \\
\hline \multicolumn{5}{|c|}{ L. alba + L. origanoides + L. sidoides } \\
\hline 10 & $4 \mathrm{~h} 17 \min ^{\mathrm{a}^{*}}$ & 14 & 12 & 85.71 \\
\hline 20 & $4 \mathrm{~h} 12 \min ^{\mathrm{a} *}$ & 15 & 13 & 86.67 \\
\hline 40 & $3 \mathrm{~h} 16 \min ^{\mathrm{b}}$ & 27 & 27 & 100.00 \\
\hline 60 & $32 \min ^{\mathrm{c}}$ & 43 & 43 & 100.00 \\
\hline 80 & $10 \min ^{\mathrm{d}}$ & 26 & 26 & 100.00 \\
\hline 100 & $9 \min ^{\mathrm{d}}$ & 39 & 39 & 100.00 \\
\hline
\end{tabular}

"Identical to water control. "Identical to alcohol control. Different letters indicate significant difference (p<0.05) among concentrations in the same treatment, by Tukey's test. 
Table 2. Zootechnical parameters (mean \pm standard deviation) from Koi carp fed supplemented diets with different concentrations of Lippia sidoides essential oil. WG: weight gain, SL: standard length, PER: protein efficiency rate, MIFI: mean individual feed intake, AFC: apparent feed conversion, SGR: specific growth rate, SR: survival rate.

\begin{tabular}{ccccccc}
\hline \multicolumn{7}{c}{ Concentration of essential oil of Lippia sidoides } \\
\hline Parameters & Control & $\mathbf{0 . 2 5 \%}$ & $\mathbf{0 . 5 0 \%}$ & $\mathbf{0 . 7 5 \%}$ & $\mathbf{1 . 0 \%}$ & $\boldsymbol{p}$ \\
\hline WG & $3.79 \pm 0.44^{\mathrm{a}}$ & $3.89 \pm 0.31^{\mathrm{a}}$ & $2.67 \pm 0.29^{\mathrm{ab}}$ & $2.38 \pm 0.70^{\mathrm{b}}$ & $3.23 \pm 0.56^{\mathrm{ab}}$ & 0.011 \\
SL $(\mathrm{cm})$ & $3.54 \pm 0.18$ & $3.48 \pm 0.22$ & $3.29 \pm 0.57$ & $3.26 \pm 0.32$ & $3.61 \pm 0.65$ & 0.812 \\
PER & $0.92 \pm 0.13^{\mathrm{a}}$ & $0.94 \pm 0.10^{\mathrm{a}}$ & $0.67 \pm 0.08^{\mathrm{ab}}$ & $0.58 \pm 0.17^{\mathrm{b}}$ & $0.80 \pm 0.13^{\mathrm{ab}}$ & 0.020 \\
MIFI & $0.07 \pm 0.00$ & $0.07 \pm 0.00$ & $0.07 \pm 0.00$ & $0.07 \pm 0.00$ & $0.07 \pm 0.00$ & 0.294 \\
AFC & $0.02 \pm 0.00$ & $0.02 \pm 0.00$ & $0.03 \pm 0.00$ & $0.03 \pm 0.00$ & $0.02 \pm 0.00$ & 0.069 \\
SGR & $6.32 \pm 0.73^{\mathrm{a}}$ & $6.48 \pm 0.52^{\mathrm{a}}$ & $4.45 \pm 0.48^{\mathrm{ab}}$ & $3.97 \pm 1.16^{\mathrm{b}}$ & $5.38 \pm 0.93^{\mathrm{ab}}$ & 0.011 \\
SR $(\%)$ & 100 & 100 & 100 & 100 & 100 & - \\
\hline
\end{tabular}

WG: weight gain, SL: standard length, PER: protein efficiency rate, MIFI: mean individual feed intake, AFC: apparent feed conversion, SGR: specific growth rate, SR: survival rate. Different letters indicate significant difference among treatments by Tukey's test $(\mathrm{p}<0.05)$.

Table 3. Parasitological indexes (mean \pm standard deviation) of monogeneans from Koi carp in net tanks, fed control and supplemented diets with $0.25 \%, 0.5 \%, 0.75 \%$ and $1 \%$ of essential oil from Lippia sidoides

\begin{tabular}{lcccccccccc}
\hline & & \multicolumn{4}{c}{ 30 Days } & \multicolumn{4}{c}{ 60 Days } \\
\hline TR & IS & P (\%) & MA & MD & MI & P $(\%)$ & MA & MD & MI \\
\hline \multirow{2}{*}{0.00} & M & 0 & 0 & 0 & 0 & 0 & 0 & 0 & 0 \\
& G & 66.67 & $1.44 \pm 1.01$ & $0.05 \pm 0.03$ & $2.06 \pm 1.29$ & 72.22 & $2.56 \pm 1.58$ & $0.15 \pm 0.09$ & $3.42 \pm 1.77$ \\
0.25 & M & 0 & 0 & 0 & 0 & 0 & 0 & 0 & 0 \\
& G & 66.68 & $3.22 \pm 1.82$ & $0.82 \pm 1.16$ & $3.38 \pm 1.84$ & 83.33 & $6.89 \pm 2.83$ & $0.21 \pm 0.08$ & $8.27 \pm 3.40$ \\
0,50 & M & 0 & 0 & 0 & 0 & 0 & 0 & 0 & 0 \\
& G & 61.11 & $3.50 \pm 6.06$ & $0.06 \pm 0.1$ & $4.20 \pm 7.27$ & 55.56 & $2.56 \pm 1.66$ & $0.09 \pm 0.06$ & $4.72 \pm 1.39$ \\
0.75 & M & 0 & 0 & 0 & 0 & 0 & 0 & 0 & 0 \\
& G & 61.48 & $1.67 \pm 1.74$ & $0.06 \pm 0.06$ & $2.22 \pm 1.95$ & 66.67 & $3.83 \pm 2.20$ & $0.09 \pm 0.05$ & $5.40 \pm 1.31$ \\
1.00 & M & 0 & 0 & 0 & 0 & 0 & 0 & 0 & 0 \\
& G & 72.22 & $2.11 \pm 0.91$ & $0.06 \pm 0.02$ & $1.91 \pm 0.62$ & 77.78 & $3.83 \pm 2.58$ & $0.17 \pm 0.11$ & $5.58 \pm 3.45$ \\
\hline
\end{tabular}

Treatment (TR), prevalence (P\%), mean abundance (MA), mean dominance (MD), mean intensity (MI), infestation site (IS), gills (G), mucus from body surface (M).

Also, there was a prevalence of 83.33 to $55.56 \%$ of monogeneans in concentrations of 0.25 and $0.50 \%$ of the oil in the diet after 60 days of supplementation. Among the trichodinids, the prevalence was 100 and $66.67 \%$ at concentrations of 0.25 and $1.0 \%$ of the oil in the diet in 60 days. Parasitological indices such as prevalence, mean abundance, mean dominance and mean intensity of the identified groups did not show significant differences $(\mathrm{p}>$ 0.05 ) among treatments, both at 30 and 60 days (Tables 3 and 4).

\section{Discussion}

\section{Chemical composition of the essential oils of Lippia spp.}

In this study, different species of the genus Lippia presented different major compounds, corroborating other authors (76), who also found variations in the content and chemical composition of the essential oils of the same plant species. These variations in the chemical composition of Lippia may be related to soil type, environmental factors, collection period, seasonal variation and month $(73,37)$.

Analyses of the chemical composition of $L$. sidoides oil indicated that thymol and p-cymene are the major chemical components. These results corroborate those obtained in other studies $(21,28,51,77)$, which, although obtaining different percentage values, also listed thymol and p-cymene as the most abundant components in the essential oil of this species. Studies with isolated thymol have proven its antimicrobial activity. A comparison between the antimicrobial activity of Lippia sidoides oil and its major compound, thymol, against bacteria (Streptococcus aureus, S. mutans, Klebsiella pneumoniae, Providencia rettgeri, Enterobacter cloacae, Enterococcus faecalis, Pseudomonas aeruginosa and Escherichia coli) was performed, and there was no difference in antimicrobial effect between essential oil and isolated thymol, evidencing that it is the component responsible for the antimicrobial activity (86). Thymol alone, at a concentration of $10 \mathrm{mg} \mathrm{mL}^{-1}$, has antibacterial activity against $S$. mutans (13). 
Table 4. Parasitological indexes (mean \pm standard deviation) of trichodinids from Koi carp in net tanks, fed control and supplemented diets with $0.25 \%, 0.5 \%, 0.75 \%$ and $1 \%$ of essential oil from Lippia sidoides.

\begin{tabular}{ccccccccccc}
\hline & \multicolumn{1}{c}{ 30 Days } & \multicolumn{4}{c}{ 60 Days } \\
\hline TR & IS & P (\%) & MA & MD & MI & P (\%) & MA & MD & MI \\
\hline \multirow{2}{*}{0.00} & M & 88.89 & $9.17 \pm 3.24$ & $0.28 \pm 0.1$ & $10.08 \pm 1.72$ & 77.78 & $2.83 \pm 2.36$ & $0.17 \pm 0.14$ & $3.35 \pm 2.72$ \\
& G & 0 & 0 & 0 & 0 & 0 & 0 & 0 & 0 \\
0.25 & M & 83.33 & $4.61 \pm 0.75$ & $0.18 \pm 0.03$ & $5.56 \pm 0.21$ & 88.89 & $3.61 \pm 1.41$ & $0.11 \pm 0.04$ & $4.00 \pm 1.24$ \\
& G & 0 & 0 & 0 & 0 & 0 & 0 & 0 & 0 \\
0.50 & M & 83.33 & $34.89 \pm 42.06$ & $0.24 \pm 0.11$ & $16.87 \pm 7.91$ & 100 & $6.06 \pm 2.27$ & $0.23 \pm 0.08$ & $9.89 \pm 6.09$ \\
& G & 0 & 0 & 0 & 0 & 0 & 0 & 0 & 0 \\
0.75 & M & 77.78 & $7.78 \pm 6.01$ & $0.27 \pm 0.21$ & $9.37 \pm 6.64$ & 100 & $9.28 \pm 6.09$ & $0.23 \pm 0.15$ & $9.28 \pm 6.09$ \\
& G & 0 & 0 & 0 & 0 & 0 & 0 & 0 & 0 \\
1.00 & M & 94.44 & $8.56 \pm 4.58$ & $0.25 \pm 0.13$ & $8.98 \pm 4.33$ & 66.67 & $3.67 \pm 2.72$ & $0.16 \pm 0.12$ & $6.33 \pm 6.04$ \\
& G & 0 & 0 & 0 & 0 & 0 & 0 & 0 \\
\hline
\end{tabular}

Treatment (TR), prevalence (P\%), mean abundance (MA), mean dominance (MD), mean intensity (MI), infestation site (IS), gills (G), mucus from body surface (M).

In L. origanoides oil, p-cymene was the most abundant compound, followed by carvacrol and $\gamma$ terpinene. These results differ from those obtained in other studies $(51,4)$, which found a higher proportion of carvacrol (41.1-49.7\%), with p-cymene being the second most abundant compound. Isolated carvacrol from $L$. origanoides showed antifungal activity against $A$. fumigatus and A. flavus (10), and p-cymene from the same plant was effective against Trypanosoma cruzi and Leishmania chagasi (28). In L. alba essential oil, the major compounds were carvone and limonene. Carvone ranged from 54.5 to $61.7 \%$ and limonene from 17.5 to $23.1 \%$, similar to previous results $(39,76)$. Isolated carvone has antifungal, antimicrobial, anti-quorum sensing, insecticidal and insect-repellent properties $(66,11,67)$.

In vitro analysis of the essential oils of Lippia spp. against monogeneans of koi carp

Essential oil of L. sidoides showed $100 \%$ efficacy in vitro against koi carp monogeneans at $40 \mathrm{mg} \mathrm{L}^{-1}$ for 8 min. This dose was lower than those used in other effective treatments against monogenean parasites from other fish species $(50,72)$. A $100 \%$ efficacy in vitro for $L$. sidoides essential oil was observed against monogeneans from tambaqui (Colossoma macropomum) after $10 \mathrm{~min}$ exposure to $320 \mathrm{mg} \mathrm{L}^{-1}$, while those exposed to $160 \mathrm{mg} \mathrm{L}^{-1}$ showed total mortality only after $1 \mathrm{~h}$ (76). Other studies report $100 \%$ mortality of the monogeneans Cichlidogyrus tilapiae Paperna, 1960, Cichlidogyrus thurstonae Ergens, 1981, Cichlidogyrus halli, Price and Kirk, 1967 and Scutogyrus longicornis Paperna and Thurston, 1969 from Nile tilapia with L. sidoides oil at $160 \mathrm{mg} \mathrm{L}^{-1}$ for 60 s. (38). One hundred efficacy was found for Melaleuca alternifolia and Mentha piperita essential oils against monogeneans from pacu Piaractus mesopotamicus at $400 \mathrm{mg} \mathrm{L}^{-1}$ and for Copaifera duckei oleoresin at $100 \mathrm{mg} \mathrm{L}^{-1}$ after $60 \mathrm{~min}$ (20).
In the present study, oedema, vacuolisation and lysis of monogenean parasites were produced by essential oils from all Lippia species at concentrations of 40, 60, 80 and $100 \mathrm{mg} \mathrm{L}^{-1}$. Similar observations have been reported in other studies (20) with copaiba ( $C$. duckei) oleoresin, which produced swelling and lysis of the monogenean parasites from $P$. mesopotamicus, suggesting that its mode of action affecting cell membrane permeability. The same effect occurred with oils from Lavandula angustifolia, Melaleuca alternifolia and Mentha piperita, resulting in signs of swelling, vacuolisation, lysis and death of trophonts of Ichthyophthirius multifiliis Fouquet, 1876 from pacu P. mesopotamicus (85). Swelling and lysis have also been reported in studies with trophonts of I. multifiliis from grass carp (Ctenopharyngodon idella), which showed transparent bubbles in the plasma membrane, cytoplasmic damages, loss of membrane integrity and death after exposure to cynatratoside-C extracted from Cynanchum atratum root (35). These effects, classified as permeabilization of the cellular membrane, were observed in the protozoan parasite I. multifiliis from the gills of the channel catfish Ictalurus punctatus when exposed to pentagalloylglucose, extracted from Galla chinensis (90). The temporary neutralisation of parasites at concentrations of 10 and $20 \mathrm{mg} \mathrm{L}^{-1}$ in all treatments may be related to the anaesthetic action exerted by $L$. alba, L. origanoides and $L$. sidoides $(70,76)$. Thus, this result serves as an alert for a careful use of Lippia essential oils for in vitro tests against monogeneans, since this neutralising effect may mask the result over the mortality time of the parasites. Therefore, cautious monitoring of the exposure time of organisms to solutions that present compounds with anaesthetic potential is recommended.

In vivo test with essential oil of Lippia sidoides 
Monitoring zootechnical performance during in vivo tests with phytotherapics is fundamental to verify if the tested product has some anti-nutritional factors, which could result in impaired growth and survival. In the present study, fish fed $0.75 \%$ essential oil showed reductions in zootechnical performance compared to control fish; however, those fed $1 \%$ essential oil did not demonstrate such results. Regarding growth, some studies have shown positive effects of other kind of essential oil in the diet (14, $2,8,16)$.

In the present study, L. sidoides oil did not influence parasite load after 60 days. For trichodinids, there was a prevalence of 100 and $66.67 \%$, a mean intensity of 6.33 and 9.89 at concentrations of 0.25 and $1.0 \%$ of $L$. sidoides essential oil, respectively. In the form of therapeutic baths, 3 ppt of garlic oil showed $74 \%$ efficacy after $1 \mathrm{~h}$ exposition against Trichodina in Nile tilapia and $100 \%$ efficacy using crude garlic and Indian almond extracts at $800 \mathrm{ppm} 2$ days after treatment; however, the parasites reappeared after two weeks (1). The aqueous extract from Artemisia vulgaris at $800 \mathrm{mg} \mathrm{L}^{-1}$ of garlic for 5 days was effective against Trichodina sp. and Aeromonas hydrophila in tilapia (62).

Similarly, in studies with pufferfish Takifugu rubripes fed peppermint and cinnamon oils at $2.5 \mathrm{~g} \mathrm{~kg}^{-1}$ for 20 days, there was no effect on parasitism by Heterobothrium okamotoi Ogawa, 1991, (41). Ineffectiveness was also identified regarding dietary supplementation with ginger extract against Gyrodactylus turnbulli Harris, 1986, in Poecilia reticulata (49). In this study, both the control and treatments had similar results regarding parasitological indices.

Different from the present study, in other studies, phytotherapeutics in the diet have shown positive results against monogeneans $(59,24,32,93)$. It is possible that in the present study, the tested doses of $L$. sidoides essential oil were not high enough to eliminate parasites. Therefore, higher concentrations would be required but always assessing the possible toxic aspects about these doses. In another study, grass carp (Ctenopharyngodon idella) coinfected with D. ctenopharyngodonid and I. multifiliis were fed $4 \%$ Astragalus membranaceus, Allium sativum, Morus alba and Glycyrrhiza uralensis and treated with baths containing ginger extract at $4 \mathrm{mg} \mathrm{L}^{-1}$, reaching $100 \%$ effectiveness at 28 days of treatment (34).

Dietary treatment is the preferred way for the administration of therapeutic products to fish, allowing treatment of fish of all sizes and in all life stages and preventing mortality. As there is no need to capture individuals, stress and injuries are largely avoided, and in addition, other diseases can be treated simultaneously, resulting in lower costs and increased immune responses and resistance to diseases $(48,14)$.

Dactylogyrus minutus and D. extensus, observed in this study parasitising koi carp gills, are generally found in these organs and can also occur in the nasal cavities of fish (65). This corroborates the findings of other studies with koi carp, where $D$. minutus was the most abundant parasite in the gill filaments of this fish $(26,71)$. In the present study, $T$. reticulata, $T$. heterodentata and Trichodina sp. were identified on the body surface of koi carp (54), while in another study, $T$. reticulata was identified for the first time in Brazil, parasitising the skin of $C$. auratus, which belongs to the same family as the koi carp (71). The species of Trichodina are not specific for koi carp, with $T$. reticulata occurring in $C$. carpio (25) and $T$. heterodentata in the common carp C. carpio (9) and in the piauçu Leporinus macrocephalus (84). Trichodina heterodentata has also been reported in Rhinella pombali tadpoles (29). Trichodinids are the parasitic agents that most affect fish worldwide (43); they are generally found in the skin and gills, where they cause itching, irritation and other clinical signs. In outbreaks of these parasites, fish present necrosis of the epidermis and erosion of the fins. Carps with immunosuppression or disease may be more affected by trichodinids (68), which serves as a justification for future studies to check the effects of the essential oils on the immune response, and consequently, on disease resistance.

\section{Conclusion}

The essential oil from $L$. sidoides was effective in vitro against monogenean parasites at concentrations of 40 , 60,80 and $100 \mathrm{mg} \mathrm{L}^{-1}$. However, it was not effective in the in vivo test against koi carp parasites at $0.25,0.5,0.75$ and $1.0 \%$ in the diet. No improvement of the zootechnical performance of the fish was found. Further studies are recommended with other doses to verify its potential to increase disease resistance by enhancing the immune response, as well as the use of the oil in therapeutic baths to reduce parasitism.

\section{Acknowledgements}

This study was financed in part by the Coordination of Improvement of Higher Education Personnel, Brazil (CAPES) - Finance Code 001. The authors thank CAPES for PhD scholarship to E.M. Brasil and National Council for Scientific and Technological Development (CNPq) for Research Grant to M.L. Martins (CNPq 305869/2014-0, 306635/2018-6) and J.L.P. Mouriño (CNPq 308292/2014-6).

\section{References}

1. Abd El-Galil MAA, Aboelhadid SM. Trials for the control of trichodinosis and gyrodactylosis in hatchery reared Oreochromis niloticus fries by using garlic. Vet Parasitol. 2012;185(2):57-63.

2. Acar Ü, Kesbiç OS, Yılmaz S, Gültepe N, Türker A. Evaluation of the effects of essential oil extracted from sweet orange peel (Citrus sinensis) on growth rate of tilapia (Oreochromis mossambicus) and possible 
disease resistance against Streptococcus iniae. Aquaculture. 2015;437:282-6.

3. Adams RP. Identification of essential oils components by gas chromatography/mass spectrometry. 4th ed. Carol Stream: Allured Publishing Corporation; 2007. 804 p.

4. Almeida RR, Damasceno ETS, Carvalho SYB, Carvalho GSG, Gontijo LAP, Lima Guimarães LG. Chitosan nanogels condensed to ferulic acid for the essential oil of Lippia origanoides Kunth encapsulation. Carb Polym. 2018;188(1):268-75.

5. Andrade VA, Almeida AC, Souza DS, Colen KGF, Macêdo AA, Martins ER, Fonseca FSA, Santos RL. Antimicrobial activity and acute and chronic toxicity of the essential oil of Lippia origanoides. Pesq Vet Bras. 2014;34:1153-61.

6. Azambuja CR, Mattiazzi J, Riffel APK, Finamor IA, Oliveira LG, Heldwein CG, Llesuy SF. Effect of the essential oil of Lippia alba on oxidative stress parameters in silver catfish (Rhamdia quelen) subjected to transport. Aquaculture. 2011;319(1-2): 156-61.

7. Baba E, Acar Ü, Öntaş C, Kesbiç OS, Yılmaz S. Evaluation of Citrus limon peels essential oil on growth performance, immune response of Mozambique tilapia Oreochromis mossambicus challenged with Edwardsiella tarda. Aquaculture. 2016;465(1):13-8.

8. Basson L, Van JG. Trichodina ectoparasites (Ciliophora: Peritrichida) of wild and cultured freshwater fishes in Taiwan, with notes on their origin. Syst Parasitol. 1994;28 (3): 197-222.

9. Betancur-Galvis L, Zapata B, Baena A, Bueno J, RuízNova CA, Stashenko E, Mesa-Arango AC. Antifungal, cytotoxic and chemical analyses of essential oils of Lippia origanoides HBK grown in Colombia. Salud. 2011;43(2):141-8.

10. Boonruang K, Kerddonfag N, Chinsirikul W, Mitcham EJ, Chonhencho V. Antifungal effect of poly (lactic acid) films containing thymol and R- (-)-carvone against anthracnose pathogens isolated from avocado and citrus. Food Control. 2017;78(1):85-93.

11. Borji H, Naghibi A, Nasiri MR, Ahmadi A. Identification of Dactylogyrus spp. and other parasites of common carp in northeast of Iran. J Paras Dis. 2012;36(2):234-8.

12. Botelho MA, Nogueira NAP, Bastos GM, Fonseca SGC, Lemos TLG, Matos FJA, Montenegro, Heukelbach DJ, Rao VS, Brito GAC. Antimicrobial activity of the essential oil from Lippia sidoides, carvacrol and thymol against oral pathogens. Braz $\mathbf{J}$ Med Biol Res. 2007;40(3):349-56.

13. Brum A, Pereira AS, Owatari MS, Chagas EC, Chaves FCM, Mouriño JLP, Martins ML. Effect of dietary essential oils of clove basil and ginger on Nile tilapia (Oreochromis niloticus) following challenge with
Streptococcus agalactiae. Aquaculture. 2017;468(1):235-43.

14. Bush AO, Lafferty KD, Lotz JM, Shostak AW. Parasitology meets ecology on its own terms: Margolis et al. revisited. J Parasitol. 1997;83(4):57583.

15. Campagnolo R, Fresccia A, Bergmann RR, Meurer F, Bombardelli RR, Meurer FF, Bombardelli RA. Óleos essenciais na alimentação de alevinos de tilápia do Nilo. Rev Bras Saúde Prod Anim. 2013;14(3):565-73.

16. Castro CE, Ribeiro, JM, Diniz TT, Almeida AC, Ferreira LC, Martins ER, Duarte ER. Antimicrobial activity of Lippia sidoides Cham. (Verbenaceae) essential oil against Staphylococcus aureus and Escherichia coli. Rev Bras Plantas Med. 2011;13(3):293-7.

17. Conde R, Corrêa VSC, Carmona F, Contini SHT, Pereira AMS. Chemical composition and therapeutic effects of Lippia alba NE Brown leaves hydroalcoholic extract in patients with migraine. Phytomedicine. 2011;18(14):1197-201.

18. Costa DCM, Vermelho AB, Almeida CA, Dias EPDS, Cedrola SML, Arrigoni-Blank MDF, Alviano CS, Alviano DS. Inhibitory effect of linalool-rich essential oil from Lippia alba on the peptidase and keratinase activities of dermatophytes. J Enz Inhib Med Chem. 2014;29(1):12-7.

19. Costa JC, Valladão GMR., Pala G, Gallani SU, Kotzent S, Crotti AEM, Fracarollic L, Mangabeirada JJ, Silva Pilarski F. Copaifera duckei oleoresin as a novel alternative for treatment of monogenean infections in pacu Piaractus mesopotamicus. Aquaculture. 2017;471(1):72-9.

20. Costa JGM, Rodrigues FFG, Silva EC, Mota MR, Santos NKA, Cardoso, ALH, Lemos TLG. Estudo químico-biológico dos óleos essenciais de Hyptis martiusii, Lippia sidoides e Syzigium aromaticum frente às larvas do Aedes aegypti. Rev Bras Farmacog. 2005;15(4):304-9.

21. Dairiki JK, Majolo C, Chagas EC, Chaves FCM, Oliveira MR, Morais IDS. Procedimento para inclusão de óleos essenciais em rações para peixes. Manaus (AM). 2013. 8 p.

22. Dehghan F, Vazirzadeh A, Soltanian S, Karami A, Akhlaghi M. Mortality rate and immune responses of rainbow trout (Oncorhynchus mykiss) infected with Yersinia ruckeri subsequent to feeding on diet supplemented with Ducrosia anethifolia essential oil. Int J Aquat Biol. 2016;4(5):340-4.

23. Dotta G, Brum A, Jeronimo GT, Maraschin M, Martins ML. Effect of dietary supplementation with propolis and Aloe barbadensis extracts on hematological parameters and parasitism in Nile tilapia. Braz. J Vet Parasitol. 2015;24(1):66-71.

24. Dove ADM, Peter JO. Trichodinids (Ciliophora: Trichodinidae) from Native and Exotic Australian Freshwater Fishes. Acta Protozool. 2005;44(2):51-60. 
25. Dzika E, Dzikowec M, Hoffmann RW. Description of the development of the attachment and copulatory apparatus of Dactylogyrus extensus from Cyprinus carpio var. koi. Parasitol Inst SAS. 2009;46(1):39-44.

26. Eiras JC, Takemoto RM, Pavanelli GC. Diversidade dos parasitas de peixes de água doce do Brasil. $1^{\text {st }}$ ed. Maringá: Clichetec; 2010. 333 p.

27. Escobar P, Leal SM, Herrera LV, Martinez JR, Stashenko E. Chemical composition and antiprotozoal activities of Colombian Lippia spp. essential oils and their major components. Mem Inst Oswaldo Cruz. 2010;105(2):184-90.

28. Fernandes NM, Sartini B, Dias RJP, D'Agosto M. Quantitative study of Trichodina heterodentata (Ciliophora: Mobilia) infrapopulations infesting tadpoles of a Brazilian endemic toad Rhinella pombali (Anura: Bufonidae). Zoologia. 2011;28(6):777-83.

29. Fontenelle ROS, Morais SM, Brito EHS, Kerntopf MR, Brilhante RSN, Cordeiro RA, Tomé AR, Queiroz MGR, Nascimento NRF, Sidrim JJC, Rocha MFG. Chemical composition, toxicological aspects and antifungal activity of essential oil from Lippia sidoides Cham. J Antimicrob Chemoth. 2007;59(5):934-40.

30. Fracalossi DM, Cyrino JEP. Nutrição e alimentação de espécies de interesse para a aquicultura brasileira. 1st ed. Florianópolis: Sociedade Brasileira de Aquicultura e Biologia Aquática; 2012. 375 p.

31. Fridma S, Sinai T, Zilberg D. Efficacy of garlic based treatments against monogenean parasites infecting the guppy (Poecilia reticulata (Peters)). Vet Parasitol. 2014;203(1-2):51-8.

32. Fu YW, Wang B, Zhang QZ, Xu DH, Lin DJ, Yang XY, Zhu SQ, Pan JY, Deng Q, Liu YM, Zhou SY. Combined effects of Chinese medicine feed and ginger extract bath on co-infection of Ichthyophthirius multifiliis and Dactylogyrus ctenopharyngodonid in grass carp. Parasitol Res. 2017;116(7):2017-25.

33. Fu YW, Zhang QZ, Xu D, Liang, JH, Wang B. Antiparasitic Effect of Cynatratoside $\mathrm{C}$ from Cynanchum atratum against Ichthyophthirius multifiliis on Grass Carp. J Agric Food Chem. 2014;62(29):7183-9.

34. Gomes AF, Almeida MP, Leite MF, Schwaiger S, Stuppner H, Halabalaki M, Amaral JG, David JM. Seasonal variation in the chemical composition of two chemotypes of Lippia alba. Food Chem. 2019;273(1):186-93.

35. Hashimoto GSO, Neto FM, Ruiz ML, Acchile M, Chagas EC, Chaves, FCM, Martins ML. Essential oils of Lippia sidoides and Mentha piperita against monogenean parasites and their influence on the hematology of Nile tilapia. Aquaculture. 2016;450(1):182-6.

36. Hatano VY, Torricelli AS, Giassi ACC, Coslope LA, Viana MB. Anxiolytic effects of repeated treatment with an essential oil from Lippia alba and (R) (-)- carvone in the elevated T-maze. Braz J Med Biol Res. 2012;45(3):238-43.

37. Heinzmann BM, Barro FMC. Potencial das plantas nativas brasileiras para o desenvolvimento de fitomedicamentos tendo como exemplo Lippia alba (Mill.) n. e. brown (verbenaceae). Saúde. 2007;33(1):43-8.

38. Heldwein CG, Silva LDL, Gai EZ, Roman C, Parodi TV, Bürger ME, Baldisserotto B, Flores EMM, Heinzmann BM. S-(+)-Linalool from Lippia alba: sedative and anesthetic for silver catfish (Rhamdia quelen). Vet Anaesth Analog. 2014;41(6):621-9.

39. Hirazawa N, Ohtaka T, Hata K. Challenge trials on the anthelmintic effect of drugs and natural agents against the monogenean Heterobothrium okamotoi in the tiger puffer Takifugu rubripes. Aquaculture. 2000;188(12):1-13.

40. Jerônimo GT, Marchiori NC, Pádua SB, Neto JD, Pilarski F, Ishikawa MM, Martins ML. Trichodina colisae (Ciliophora: Trichodinidae): new parasite records for two freshwater fish species farmed in Brazil. Braz J Vet Parasitol. 2012;21(4):366-71

41. Jerônimo GT, Tavares-Dias M, Martins, ML, Ishikawa MM. Manual para coleta de parasitos em peixes de cultivos. Brasília (DF). Embrapa; 2012. 36 p.

42. Jiang C, Wu ZQ, Liu L, Liu GL, Wang GX. Synergy of herbal ingredients combination against Dactylogyrus spp. in an infected goldfish model for monogenean management. Aquaculture 2014;433(1):115-8.

43. Klein BM. The dry silver method and its proper use. J Protozool. 1958;5(2):99-103.

44. Kritsky DC, Heckmann R. Species of Dactylogyrus (Monogenoidea: Dactylogyridae) and Trichodina mutabilis (Ciliata) infesting koi carp, Cyprinus carpio, during mass mortality at a commercial rearing facility in Utah, USA. Comp Parasitol. 2002;69(2):217-8.

45. Kulwiec Z. Untersuchungen an Arten des Genus Dactylogyrus Diesing. Bull Acad Polonaise Sci Lett. 1927;2(1):113-44.

46. Leibowitz MP, Chettri JK, Ofir R, Zilberg D. Treatment development for systemic Tetrahymena sp. infection in guppies, Poecilia reticulata Peters. J Fish Dis. 2010;33(6):473-80.

47. Levy G, Zilberg D, Paladini G, Fridman, S. Efficacy of ginger-based treatments against infection with Gyrodactylus turnbulli in the guppy (Poecilia reticulate (Peters)). Vet Parasitol. 2015;209(3-4):23541.

48. Magalhães ALB, Jacobi CM. E-commerce of freshwater aquarium fishes: potential disseminator of exotic species in Brazil. Acta Sci. 2010;2(3):243-8.

49. Majolo C, Rocha SIB, Chagas EC, Chaves FCM, Bizzo HR. Chemical composition of Lippia spp. essential oil and antimicrobial activity against 
Aeromonas hydrophila. Aquac Res. 2017;48(5):23807.

50. Malheiros DF, Maciel PO, Videira MN, Tavares-Dias M. Toxicity of the essential oil of Mentha piperita in Arapaima gigas (pirarucu) and antiparasitic effects on Dawestrema spp. (Monogenea). Aquaculture. 2016;455(1):81-6.

51. Marco CA, Teixeira E, Simplício A, Oliveira C, Costa J, Feitosa J. Chemical composition and allelopathyc activity of essential oil of Lippia sidoides Cham. Chilean J Agric Res. 2012;72(1):157-60.

52. Martins ML, Marchiori N, Roumbedakis K, Lami F. Trichodina nobilis Chen, 1963 and Trichodina reticulate Hirschmann et Partsch, 1955 from ornamental freshwater fishes in Brazil. Braz $\mathrm{J}$ Biol. 2012;72(2):281-6.

53. Martins ML, Mouriño JLP, Chagas EC, Silva BC, Fujimoto RY, Pádua SB. Ectoparasitários na aquicultura. In: Baldisserotto B, Gomes LC, Heinzmann BM, Cunha MA. Farmacologia aplicada à aquicultura. Santa Maria: Editora da UFSM, 2017. p. 127-81.

54. Martins ML, Cardoso L, Furtado, WE, Tancredo KR, Lehmann NB, Figueiredo AB, Steckert LD, Silva KAG, Padua SB, Ferreira TH. Histopathology guide for freshwater fish. 1st ed. Florianópolis: Editora da UFSC; 2018. $62 \mathrm{p}$.

55. Mattos SH, Innecco R, Marco CA. Araújo AV. Plantas medicinais e aromáticas cultivadas no Ceará: tecnologia de produção e óleos essenciais. Banco do Nordeste do Brasil. 2007;1(1):61-3.

56. Matos F.J.A. As ervas cidreiras do Nordeste do Brasil - Estudo de três quimiotipos de Lippia alba (Mill.) N.E Brown (Verbenaceae). Parte II - Farmacoquímica. Rev Bras Farmácia. 1996;77:137-41.

57. Militz TA, Southgate PC, Carton AG, Hutson KS. Dietary supplementation of garlic (Allium sativum) to prevent monogenean infection in aquaculture. Aquaculture. 2013;408-409:95-9.

58. Mueller JF, Van Cleave HJ. Parasites of Oneida Lake fishes. Part II. Descriptions of new considerations, especially, concerning the trematoda family Heterophyidae. Roosevelt Wild Life Ann. 1932;111(2):79-137.

59. Noor El Deen AIE, Mohamed RA. Application of some medicinal plants to eliminate Trichodina sp. in tilapia (Oreochromis niloticus). Report and Opinion. 2009;12(17):1.

60. Pádua SB, Martins ML, Carraschi SP, Cruz C, Ishikawa MM. Trichodina heterodentata (Ciliophora: Trichodinidae): a new parasite for Piaractus mesopotamicus (Pisces: Characidae). Zootaxa. 2012;3422:62-8.

61. Pahor-Filho E, Júnior JP, Pilarski F, Urbinati EC. Levamisole reduces parasitic infection in juvenile pacu (Piaractus mesopotamicus). Aquaculture. 2017;470:123-8.
62. Pavanelli GC, Eiras JC, Takemoto RM. Doenças de peixes. Profilaxia, diagnóstico e tratamento. 3rd ed. Maringá: EDUEM; 2008. 305p.

63. Peixoto MG, Costa-Júnior LM, Blank AF, Lima AS, Menezes TSA, Santos DA, Alves PB, Cavalcanti $\mathrm{SCH}$, Bacci L, Arrigoni-Blank MF. Acaricidal activity of essential oils from Lippia alba genotypes and its major components carvone, limonene, and citral against Rhipicephalus microplus. Vet Parasitol. 2015; 210:118-22.

64. Porfírio EM, Melo HM, Pereira AMG, Cavalcante TTA, Gomes GA, Carvalho MG, Costa RA, Júnior FEAC. In vitro antibacterial and antibiofilm activity of Lippia alba essential oil, citral, and carvone against Staphylococcus aureus. Scient World J. 2017; 2017(1):1-7.

65. Portz L, Antonucci AM, Ueda BH, Dotta G, Guidelii G, Roumbedakis K, Martins ML Carniel MK, Tavechio WLG. Parasitos de peixes de cultivo e ornamentais. In: Pavanelli GC, Takemoto RM, Eiras JC, editor. Parasitologia de peixes de água doce do Brasil. Maringá: Eduem. p. 85-114.

66. Salbego J, Maia JLS, Toni C, Rodrigues ASS, Sousa EMO, Silva LVF, Mourão, RHV, Barata LES, Heinzmann BM, Baldisserotto B. Anesthesia and sedation of map treefrog (Hypsiboas geographicus) tadpoles with essential oils. Ciênc Rur. 2017;47(11):16.

67. Santos MA, Jerônimo GT, Cardoso L, Tancredo KR, Medeiros PB, Ferrarezi, JV, Gonçalves ELT, Assis GC, Martins ML. Parasitic fauna and histopathology of farmed freshwater ornamental fish in Brazil. Aquaculture. 2017;470:103-9.

68. Sarrazin SLF, Silva LA, Assunção APF, Oliveira RB, Calao VYP, Silva R, Stashenko EE, Maia JGS, Mourão RHV. Antimicrobial and Seasonal Evaluation of the Carvacrol-Chemotype Oil from Lippia origanoides Kunth. Molecules. 2015;20(2):1860-71.

69. Secex - Sistema de Análise de Informações do Comércio Exterior. Exportação e importação em geral. Brasília (DF). Ministério da Indústria, Comércio Exterior e Serviços. Comex Stat. 2018 Dec. Available from: http://comexstat.mdic.gov.br/pt/home.

70. Silveira JC, Busato NV, Costa AOS, Junior EFC. Levantamento e análise de métodos de extração de óleos essenciais. Enc Biosf. 2012;8(15):2038-52.

71. Soares BV, Tavares-Dias M. Espécies de Lippia (Verbenaceae), seu potencial bioativo e importância na medicina veterinária e aquicultura. Biota Amazônia. 2013;3(1):109-23.

72. Soares BV, Neves LR, Ferreira DO, Oliveira MSB, Chaves FCM, Chagas EC, Gonçalves RA, TavaresDias M. Antiparasitic activity, histopathology and physiology of Colossoma macropomum (tambaqui) exposed to the essential oil of Lippia sidoides (Verbenaceae). Vet Parasitol. 2017;234:49-56. 
73. Souza CF, Baldissera MD, Bianchini AE, Silva EG, Mourão RHV, Silva LVF, Schmidt D, Heinzmann BM, Baldisserotto B. Citral and linalool chemotypes of Lippia alba essential oil as anesthetics for fish: a detailed physiological analysis of side effects during anesthetic recovery in silver catfish (Rhamdia quelen). Fish Physiol Biochem. 2018;44(1):21-34.

74. Sutili FJ, Lima Silva L, Gressler LT, Battisti EK, Heinzmann BM, Vargas AC, Baldisserotto B. Plant essential oils against Aeromonas hydrophila: in vitro activity and their use in experimentally infected fish. $\mathbf{J}$ Appl Microbiol. 2015;119(1):47-54.

75. Toni C, Becker AG, Simões LN, Pinheiro CG, Lima Silva L, Heinzmann BM, Caron BO, Baldisserotto B. Fish anesthesia: Effects of the essential oils of Hesperozygis ringens and Lippia alba on the biochemistry and physiology of silver catfish (Rhamdia quelen). Fish Physiol Biochem. 2014;40(3):701-14.

76. Valentim DSS, Duarte JL, Oliveira AEMFM, Cruz RAS, Carvalho JCT, Conceicão EC, Fernandes CP, Tavares-Dias M. Nanoemulsion from essential oil of Pterodon emarginatus (Fabaceae) shows in vitro efficacy against monogeneans of Colossoma macropoтum (Pisces: Serrasalmidae). J Fish Dis. 2018;41(3):443-9.

77. Valladão GMR, Pádua SB, Gallani SU, MenezesFilho RN, Dias-Neto J, Martins ML, Ishikawa MM, Pilarski F. Paratrichodina africana (Ciliophora): a pathogenic gill parasite in farmed Nile tilapia. Vet Parasitol. 2013;197(3-4):705-10.

78. Valladão GMR, Giannecchini LG, Martins ML, Pádua SBD. Trichodina modesta: an exotic ciliate in the neotropical region parasitizing an unusual host. Braz $\mathbf{J}$ Vet Parasitol. 2015;24(2):162-7.

79. Valladão GMR, Gallani SU, Ikefuti VC, Cruz C, Levy-Pereira N, Rodrigues MVN, Pilarski F. Essential oils to control ichthyophthiriasis in pacu, Piaractus mesopotamicus (Holmberg): special emphasis on treatment with Melaleuca alternifolia. J Fish Dis. 2016;39(10):1143-52.

80. Veras NH, Rodrigues FFG, Botelho MA, Menezes IRA, Coutinho HDM, Costa JGM. Enhancement of aminoglycosides and $\beta$-lactams antibiotic activity by essential oil of Lippia sidoides Cham. and the thymol. Arab J Chem. 2017;10(2):2790-5.

81. Wing-Keong, Ng, Wang, Y. Inclusion of crude palm oil in the broodstock diets of female Nile tilapia, Oreochromis niloticus, resulted in enhanced reproductive performance compared to broodfish fed diets with added fish oil or linseed oil. Aquaculture. 2011;314(1-4):122-31.

82. Xu D, Shoemaker CA, Martins ML, Pridgeo JW, Klesiu PH. Enhanced susceptibility of channel catfish to the bacterium Edwardsiella ictaluri after parasitism by Ichthyophthirius multifiliis. Vet Microb. 2012;158(1-2):216-9.
83. Yamamoto PY. Interação genótipo $\mathrm{x}$ ambiente na produção e composição de óleos essenciais de Lippia alba (Mill.) N. E. Br. [dissertação]. [Campinas]: Instituto agronômico-USP; 2006. 90 p.

84. Zhang Q, Xu De-Hai, Klesius PH. Evaluation of an antiparasitic compound extracted from Gallachinensis against fish parasite Ichthyophthirius multifiliis. Vet Parasitol. 2013;198(1-2):45-53.

85. Zheng ZL, Tan JYW, Liu HY, Zhou XH, Xiang X, Wang KY. Evaluation of oregano essential oil (Origanum heracleoticum L.) on growth, antioxidant effect and resistance against Aeromonas hydrophila in channel catfish (Ictalurus punctatus). Aquaculture. 2009;292:214-8

86. Zoghbi MGB, Andrade EHA, Santos AS, Silva MHL, Maia JGS. Essential oils of Lippia alba (Mill.) N. E. Br. growing wild in the Brazilian Amazon. Flav Frag J. 1998;13(1):47-8.

87. Zoral MA, Futami K, Endo M, Maita M, Katagiri T. Anthelmintic activity of Rosmarinus officinalis against Dactylogyrus minutus (Monogenea) infections in Cyprinus carpio. Vet Parasitol. 2017;247:1-6. 